\title{
FEMINISME TOKOH ISTRI \\ DALAM NOVEL PEREMPUAN ITU BERMATA SAGA \\ KARYA AGUST DAPA LOKA \\ (ANALISIS ISI)
}

\author{
Supriyati ${ }^{1}$, Aswardi Pratama ${ }^{2}$ \\ Program Studi Pendidikan Bahasa dan Sastra Indonesia, \\ Fakultas Keguruan dan Ilmu Pendidikan, Universitas Batanghari, \\ Jambi \\ Bunda.zahra34@yahoo.com \\ Aswardi.pratama2012@yahoo.com
}

\begin{abstract}
The purpose of this research is to describe and archive Feminist character in the novel Perempuan Itu Bermata Saga by Agust Dapa Loka. This research is descriptive qualitative which solves the problems by describing and interpreting the objects in the form of social phenomenon on people's lives based on their reality. By using this kind of research, the research can describe data that are related to feminist aspects in the novel Perempuan Itu Bermata Saga by Agust Dapa Loka. The result of this research indicates that there are 45 eppressions which represent feminist aspects. There are 20 expressionswhich are related to well attitude in the novel Perempuan Itu Bermata Saga by Agust Dapa Loka. There are 15 expressions which are related to patience and sincere attitude. There are 10 expressions which are related to sacrifice attitude of the wife character. Based on the result of this research, it can be concluded that there are 50 expressions of feminism representation in the novel Perempuan Itu Bermata Saga by Agust Dapa Loka and the most dominant aspect occured in the novel is sincere attitude of 20 expressions.
\end{abstract}

Keywords: Feminism, Wife Character, Novel

${ }^{1}$ Dosen Program Studi Pendidikan Bahasa dan Sastra Indonesia, Fakultas Keguruan dan Ilmu Pendidikan, Universitas Batanghari Jambi

${ }^{2}$ Mahasiswa Program Studi Pendidikan Bahasa dan Sastra Indonesia, Fakultas Keguruan dan Ilmu Pendidikan, Universitas Batanghari Jambi

Feminisme Tokoh Istri dalam Novel Perempuan Itu Bermata Saga Karya Agust Dapa Loka (Analisis Isi) 


\section{PENDAHULUAN}

Karya sastra merupakan salah satu jenis hasil budaya masyarakat yang dinyatakan dalam bahasa, baik itu menggunakan bahasa lisan maupun bahasa tulisan sebagai media. Karya sastra dapat dilahirkan dan berkembangkan karena adanya dorongan dari dalam diri seorang pengarang yang dituangkan kedalam bahasa. Karya sastra diciptakan untuk dinikmati, dipahami, dihayati, dan dapat dimanfaatkan dalam kehidupan sehari-hari. "Karya sastra merupakan suatu ekspresi sastrawan, sebagai curahan perasaan atau luapan perasaan dan pikiran sastrawan, atau sebagai imajinasi sastrawan yang bekerja dengan persepsi-persepsi, pikiran-pikiran dan perasaan-perasaannya" (Wiyatmi, 2009: 12).

Karya sastra merupakan bentuk dan hasil dari sebuah pekerjaan kreatif manusia pada hakikatnya sebagai suatu media yang mendayagunakan bahasa untuk mengungkapkan tentang realita kehidupan manusia. Karya sastra pada umumnya berisi tentang permasalahan yang melingkupi kehidupan manusia. Karya sastra dapat memberikan penghayatan yang mendalam terhadap apa yang kita ketahui, menuangkan apa yang ada dipikiran kita dengan menggunakan hasil imajinasi dan daya kreasi yang kita miliki. Sebuah karya sastra itu tidak akan pernah lepas dari kehidupan manusia karena dari sebuah pengalaman hidup seorang pengarang bisa menciptakan suatu hasil karya sastra yang bisa membuat para pembaca ikut masuk kedalam cerita yang ditulis oleh seorang pengarang. Seperti novel Perempuan Itu Bermata Saga Karya Agust Dapa Loka ini adalah novel yang dikaji oleh peneliti ini berisi tentang kisah nyata dari kehidupan pengarang yaitu Agust Dapa Loka, permasalahan yang melingkupi kehidupan dan realita kehidupan manusia karena hlm tersebut maka penulis ingin sekali mengkaji novel yang berjudul Perempuan Itu Bermata Saga karya Agust Dapa Loka dalam kajian analisis feminisme.

Feminisme merupakan gerakan perjuangan para kaum hawa/wanita untuk mendapatkan kesetaraan dan persamaan derajat dengan para laki-laki. "Feminisme merupakan gerakan wanita yang menurut persamaan hak sepenuhnya antara kaum wanita dan pria. Feminisme berarti mengenai (seperti, menyerupai) wanita, bersifat kewanitaan" (Wahyuningtyas dan Santosa, 2011: 31). Inti yang diambil dari feminisme tersebut adalah bagaimana cara meningkatkan status perempuan melalui tema-tema seperti kesetaraan gender dan emansipasi wanita, feminisme ini menjadi permasalahan yang sering diangkat oleh pengarang dalam membuat karya.

Berdasarkan observasi peneliti lakukan di sejumlah perpustakaan seperti Perpustakaan Universitas Batanghari Jambi pada 10 Desember 2016, perpustakaan Universitas Jambi 15 Desember 2016 dan di perpustakaan daerah jambi tanggal 21 desember 2016. Dari ketiga tempat perpustakaan yang peneliti observasi kajian tentang feminisme ini sudah ada, tapi masih sedikit/kurang dalam mengkaji tentang feminisme tersebut khususnya pada novel Perempuan Itu Bermata Saga karya Agust Dapa Loka.

Selain itu, berdasarkan berdasarkan bacaan awal peneliti pada novel tersebut terdapat nilai-nilai positif yang ada pada tokoh istri tersebut salah satunya terdapat pada hlm. 59 dengan kutipan "Bagi istriku, cacat seumur hidup yang bakal kualami tidak ia khawatirkan. Ia justru gelisah karena meragukan daya tahanku saat menjalani amputasi”.

Nilai-nilai positif pada tokoh istri tersebut perlu diajarkan kepada semua 
wanita sejak dini mengapa, kelak wanita bakalan menjadi seorang istri dan akan menjadi seorang ibu pada anak-anaknya. Selain alasan-alasan di atas alasan lain peneliti tertarik mengkaji novel karena peneliti yakin dapat melaksanakan penelitian ini dengan baik, karena peneliti telah banyak mendapat berbagai ilmu tentang karya sastra selama menjalani perkuliahan di Universitas Batanghari Jambi.

Alasan alasan di atas itu lah yang membuat peneliti mengkaji novel yang berjudul Perempuan Itu Bermata Saga Karya Agust Dapa Loka. Keempat alasan itu yang menjadi patokan peneliti untuk senantiasa mengkaji novel tersebut menjadi bahan Skripsi untuk menyelesaikan studi dan mendapatkan gelar sarjana pendidikan.

Novel Perempuan Itu Bermata Saga menceritakan tentang orang-orang beriman. Iman yang diperkuat oleh cinta kasih dan perbuatan yang bertujuan satu memberi kebutuhan maksimal kepada setiap individu yang membutuhkan. Kisah yang inspiratif ini boleh dikatan merupakan semacam devosi terhadap cinta. Dituturkan secara sederhana namun menyentuh, kisah ini menegaskan kembali betapa kekuatan cinta dapat membangkitkan daya hidup dan menyelamatkan seseorang dari kematian mental, lebih-lebih bila terjadi tragedi atau situsi kritis yang tak terduga.

Feminisme merupakan satu gerakan yang ditunjukan untuk para perempuan yang ingin mendapatkan hak yang seharusnya ia dapatkan baik dari segi ekonomi, sosial, budaya, baik itu tidak keadilan gender dan emansipasi wanita yang harus diperjuangkan kaum perempuan.

Menurut Yoder (Yugihastuti, 2002: 139) feminisme diibaratkan sebuah quilt yang dibangun dan dibentuk dari potongan-potongan kain lembut.
Metafora ini mengandikan bahwa feminisme merupakan kajian yang mengakar kuat pada pendirian membaca sastra sebagai wanita.

Karya sastra yang bernuansa feminisme, dengan sendirinya akan begerak pada sebuah emansipasi. Kegiatan akhir dari sebuah perjuangan feminisme adalah persamaan derajat, yang hendak mendudukkan wanita tak sebagai objek. Itulah sebabnya, kajian feminisme sastra tetap memperhatikan masalah gender. Yakni, tidak saja terus menerus membicarakan citra wanita, tetapi juga seberapa kemampuan pria dalam menghadapi serangan gender tersebut.

Dapat disimpulkan dari alasanalasan yang dikemukakan di atas, ketertarikan peneliti mengkaji novel Perempuan Itu Bermata Saga karya Agust Dapa Loka sebagai berikut.

1. Pada novel tersebut terdapat nilai-nilai positif pada tokoh istri yang harus diajarkan sejak dini kepada wanita. Nilai positif tersebut seperti kesetiaan, kesabaran, ketabahan wanita dalam mengalami cobaan hidup yang mengetahui bahwa suaminya harus diamputasi.

2. Nilai-nilai positif yang terdapat pada tokoh istri tersebut harus diajarkan pada generasi sekarang mulai dari dini khususnya kaum wanita.

3. Dalam mengkaji penelitian ini maka akan menanmbah wawasan peneliti ketika menjadi seorang guru. Maka dalam penelitian ini peneliti mengambil judul Femenisme Tokoh Istri dalam Novel Perempuan Itu Bermata Saga karya Agust Dapa Loka.

Berdasarkan indentifikasi masalah di atas, menyadari keterbatasan penulis maka, penelitian ini perlu dibatasi untuk tokoh dalam novel Perempuan Itu Bermata Saga karya Agust Dapa Loka 
penulis hanya membatasi pada tokoh si sstri. Sedangkan pada aspek Feminisme penulis hanya membatasi tokoh istri sebagai seorang istri.

Berdasarkan permasalahan dalam penelitian ini jelas dan terarah, maka perlu adanya rumusan masalah. Rumusan masalah dalam penelitian ini adalah bagaimanakah aspek feminisme tokoh istri sebagai istri dalam novel Perempuan Itu Bermata Saga karya Agust Dapa Loka?

Tujuan penelitian ini merupakan sasaran yang ingin dicapai dalam penelitian ini, bedasarkan rumusan masalah yang telah diuraikan maka tujuan dari penelitian ini yaitu mendeskripsikan dan mendokumentasikan feminisme tokoh istri dalam novel Perempuan Itu Bermata Saga karya Agust Dapa Loka.

Adapun manfaat penelitian yang diperoleh dalam penelitian sastra feminisme ini yaitu ada dua manfaat, manfaat Teoretis dan manfaat Praktis di mana kedua manfaat itu saling berkaitan satu dengan yang lainnya.

Secara teoretis hasil penelitian ini diharapkan dapat menambah khasanah penelitian dalam bidang kesusastraan khususnya tentang bagaimana feminisme pada karya sastra yang berbentuk novel. Teori-teori dalam penelitian ini dapat dijadikan bahan pembanding dalam penelitian.

1. Bagi pembaca penelitian ini bermanfaat untuk memberikan informasi kepada pembaca dalam kajian karya sastra khususnya feminisme.

2. Bagi pendidikan penelitian ini bermanfaat digunakan oleh guru Bahasa dan Sastra Indonesia di sekolah sebagai materi ajar dan bahan masukan sastra terutama yang menyangkut masalah feminisme.
3. Bagi peneliti, penelitian ini bermanfaat dalam memperkaya teoriteori kajian sastra khususnya tentang kajian unsur feminisme dan teori-teori dalam penelitian ini dapat dijadikan bahan perbandingan bagi penelitian lain.

\section{METODE PENELITIAN}

Jenis penelitian sangat berperan penting dalam suatu penelitian. Menurut Rahima (2017: 1) Dalam penelitian sastra terdapat berbagai sudut pandang atau pendekatan untuk menganalisis objeknya. Perbedaan sudut pandang inilah yang kemudian memunculkan adanya berbagai jenis penelitian sastra. Pendapat tersebut dipertegas Gunawan dkk. (2018: 133) yang menjelaskan bahwa jenis penelitian merupakan cara kerja suatu penelitian yang dipilih seorang peneliti dalam memahami objek penelitian yang akan dilaksanakan. Jenis penelitian erat kaitannya dengan metode. Metode merupakan strategi atau cara untuk menyelesaikan masalah yang dikemukakan.

Dengan menggunakan pendekatan atau metode tertentu, peneliti tahu bagaimana cara mencapai tujuan suatu penelitian. Selain itu, "Jenis penelitian berfungsi untuk menyederhanakan masalah sehingga lebih mudah untuk dipecahkan dan dipahami" (Ratna, 2009: 34). Oleh sebab itu, jenis merupakan peranan penting dalam membantu menyelesaikan maslah yang dilandasi dengan sebuah keilmiahan. Menurut Rahima (2017: 1) Dalam penelitian sastra terdapat beberapa sudut pandang atau pendekatan dalam menganalisisnya. Perbedaan sudut pandang inilah yang kemudian memunculkan adanya berbagai jenis penelitian sastra, tergantung dari mana sudut pandang yang dipakai.

Secara umum menurut Sugiono (2009: 2) "Jenis penelitian adalah cara 
ilmiah untuk mendapatkan data dengan tujuan dan kegunaan tertentu" (Sugiyono, 2009: 2). Oleh karena itu, Jenis penelitian merupakan cara yang besifat ilmiah yang bertujuan untuk mendapatkan suatu hasil tertentu. Penelitian ini termasuk jenis penelitian kuliatitatif dengan metode deskriptif.

Metode Deskriptif merupakan metode yang penelitian yang bertujuan mengambarkan objek penelitian secara objektif. Metode ini digunakan untuk meneliti kutipan-kutipan yang berkaitan objek. "Jenis penelitian adalah penelitian yang berusaha menggambarkan dan menginterpretasi objek sesuai dengan apa adanya" (Sukardi, 2011: 157). Karena dalam penelitian ini tidak menggunakan kontrol dan manipulasi variabel. Jadi, data yang akan disajikan sesuai dengan kenyataannya.

Beradasarkan beberapa pendapat di atas, dapat disimpulkan bahwa penelitian ini menggunakan metode penelitian deskriptif kualitatif, karena memecahkan masalah dalam penelitian dengan bertujuan menggambarkan atau melukiskan dan menginterpretasi objek yang berupa gejala atau kejadian sosial pada kehidupan manusia sesuai dengan aslinya. Menggunakan jenis penelitian ini, peneliti dapat mendeskripsikan datadata dari objek penelitian yang berhubungan dengan aspek feminisme dalam novel Perempuan Itu Bermata Saga karya Agust Dapa Loka.

Penelitian disiplin apapun tidak bisa melepaskan diri dari data. Data merupakan sesuatu yang penting karena tanpa ada data penelitian itu tidak bisa diakui secara ilmiah. Penelitian sastra juga memerlukan data tetapi berbentuk kata, frasa, atau kalimat. "Data adalah sumber informasi yang akan diseleksi sebagai bahan analisis" (Siswantoro, 2010: 70). Data penelitian dibagi lagi menjadi dua bagian. Menurut Siswantoro data dibedakan menjadi data primer dan data sekunder.

1) Data Primer

Data primer merupakan data utama suatu penelitian data ini diambil langsung dari sumbernya "Data primer adalah data utama, yaitu data yang diseleksi atau diperoleh langsung dari sumbernya tanpa perantara" (Siswantoro, 2010:70). Data primer merupakan seluruh data yang diutamakan atau yang diwajibkan. Peranan datanya menjadi bahan pokok yang akan diteliti. Penelitian itu harus berhubungan langsung dengan sumbernya maka dikatakan primer. Data primer dalam penelitian ini adalah semua data-data yang berbentuk kutipan-kutipan yang berhubungan dengan aspek feminisme yang ditinjau dari sifat berakhlak baik, selalu sabar dan ikhlas dan berkorban yang terdapat pada novel Perempuan Itu Bermata Saga karya Agust Dapa Loka.

2) Data Sekunder

Data sekunder merupakan data yang bisa diperoleh secara tidak langsung. Data ini juga bisa disebut sebagai data pendukung untuk sebuah penelitian "Data sekunder adalah data yang diperoleh secara tidak langsung atau lewat perantara, tetapi tetap bersandar kepada kategori atau bara meter yang menjadi rujukan" (Siswantoro, 2010: 71). Data sekunder mendukung tajam atau tidaknya sebuah penelitian. Data sekunder berupa buku-buku sastra, metode penelitian sastra, internet, dan buku-buku literatur yang berkaitan dengan sifat aspek feminisme dalam novel Perempuan Itu Bermata Saga karya Agust Dapa Loka.

Subjek sangat erat kaitanya dengan sumber data. "Sumber data terkait dengan subjek penelitian dari mana data diperoleh" (Siswantoro, 2014: 72). Sumber data dalam penelitian inia dalah novel Perempuan Itu Bermata Saga 
karya Agust Dapa Loka. Cetakan pertama pada tahun 2011 yang diterbitkan oleh penerbit PT Elex Media Komputino sampul novel berwarna putih, hitam, dan merah, dengan ilustrasi gambar wajah seorang perempuan yaitu istri, dan seorang laki-laki yang duduk di atas kursi roda. Novel tersebut memiliki 199 halaman.

Teknik pengumpulan data merupakan cara peneliti untuk mengumpulkan data dalam penelitian. Teknik pengumpulan data dalam penelitian ini menggunakan teknik studi literatur dalam penelitian ini difokuskan pada aspek feminisme dalam novel Perempuan Itu Bermata Saga karya Agust Dapa Loka.

Pengumpulan data dengan studi dokumentasi. Dalam pengumpulan, data penelitian melampirkan identifikasi data dalam bentuk tabel format klasifikasi aspek feminisme dalam novel Perempuan Itu Bermata Saga karya Agust Dapa Loka. Lampiran kegiatan berbentuk tabel format klasifikasi ini bertujuan agar penelitian dapat terlaksana secara terarah dan sesuai dengan tujuannya. Teknik pengumpulan data dalam penelitian ini dilakukan dengan langkah-langkah sebagai berikut.

(1) Peneliti membaca secara berulangulang dengan cermat dan teliti, terus menerus, dan berkesinambungan keseluruhan teks novel Perempuan Itu Bermata Saga karya Agust Dapa Loka.

(2) Peneliti menandai bagian kata-kata, kalimat, dan penggalan dialog.

(3) Peneliti mencatat bagian kata-kata, kalimat, dan penggalan dialog yang menggambarkan aspek feminisme yang terkandung dalam novel Perempuan Itu Bermata Saga karya Agust Dapa Loka.
(4) Peneliti mengklasifikasikan data yang telah terkumpul sesuai dengan aspek feminisme yang di teliti.

Teknik analisis data merupakan langkah berikutnya yang dilakukan oleh peneliti. Peneliti menggunakan langkah ini agar data yang didapat sesuai dan tepat sasaran "Teknik analisis data dilakukan dengan pemaparan dalam bentuk deskriptif terhadap masingmasing data secara fungsional dan relasional" (Siswantoro, 2010: 81). Pengumpulan data dalam penelitian ini menggunakan teknik dokumentasi dan studi literatur yang difokuskan untuk menganalisis aspek feminisme sosial dalam novel Perempuan Itu Bermata Saga karya Agust Dapa Loka. Data yang diperoleh kan dijelaskan dalam bentuk deskriptif. Kegiatan analisis data dilakukan dengan langkah-langkah sebagai berikut.

(1) Data yang telah terkumpul kemudian dikelompokkan sesuai dengan aspek data diletakkan ke dalam tabel tabulasi data.

(2) Menganalisis data sesuai dengan teori yang dipergunakan.

(3) Menganalisis data berdasarkan aspek feminisme yang diperoleh dari kata, kalimat, penggalan dialog yang berkaitan dengan sifat berakhlak baik, selalu sabar dan ikhlas dan berkorban yang ada di dalam novel Perempuan Itu Bermata Saga karya Agust Dapa Loka.

(4) Mendeskripsikan data berdasarkan konsep feminisme.

(5) Merumuskan kesimpulan.

\section{HASIL DAN PEMBAHASAN}

Berikut ini dijelaskan pembahasan dari feminisme yang terdapat di dalam novel Perempuan Itu Bermata Saga karya Agust Dapa Loka tersebut. 


\section{Aspek Berakhlak Baik dalam novel Perempuan Itu Bermata Saga karya Agust Dapa Loka}

1)“Apa yang Pap rasakan Sekarang? Apa yang kubisa lakukan?" (hlm. 6)

Kutipan (1) di atas menunjukkan bahwa sang istri berperilaku baik dikarenakan ada perhatian yang diberikan kepada sang suami dengan menawarkan sesuatu yang bisa membuat sang suami bahagia.

2) "Sembilan belas tahun telah kita lewati bersama..., godaan untuk tidak saling setia," ( hlm. 19)

Kutipan (2) di atas menunjukkan bahwa sang istri berperilaku baik dikarenakan sang istri telah mendampingi suaminya selama 19 tahun dengan melewati berbagai godaan untuk saling setia.

3) "Sama-sama, Pap. Hanya itu yang dapat kukatakan... Papa istirahat saja dan kalau memungkinkan bisa tertidur." (hlm. 31)

Kutipan (3) di atas menunjukkan bahwa sang istri berperilaku baik dikarenakan selalu mengingatkan suaminya jikalau letih untuk beristirahat dan tidak melakukan aktivitas kembali.

4) "Tidak apa-apa. Sekarang aku mau siapkan air mandi untuk Papa," (hlm. 34)

Kutipan (4) di atas menunjukkan bahwa sang istri berperilaku baik dikarenakan selalu menyiapkan air untuk mandi suaminya.

5) "Diminum sajalah, Pap. Luka ini sangat parah. Pasti dosisnya disesuaikan." (hlm. 49)

Kutipan (5) di atas menunjukkan bahwa sang istri berperilaku baik dikarenakan selalu memperhatikan suaminya yang sedang terluka.
6) "Oke, sekarang Papa bergeser sedikit sambil mengangkat pantat. Hoppp.... Ya!" (hlm. 54)

Kutipan (6) di atas menunjukkan bahwa sang istri berperilaku baik dikarenakan selalu merawat sang suami yang sedang sakit.

7) "Pap, posisi kaki yang terasa nyaman seperti apa? Apakah posisinya ditinggikan atau bagaimana?" (hlm. 70)

Kutipan (7) di atas menunjukkan bahwa sang istri berperilaku baik dikarenakan selalu merawat suaminya yang sedang sakit dengan penuh perhatian.

\section{Aspek Selalu Sabar dan Ikhlas Tokoh Istri dalam Novel Perempuan Itu Bermata Saga Karya Agust Dapa Loka}

1) "Pap, jangan berpikir telah merepotkanku. Tidakkah dulu... , untuk membuktikan komitmen pernikahan kita," (hlm. 18 )

Kutipan (1) di atas menunjukkan bahwa sang istri memiliki sifat selalu sabar dan ikhlas dikarenakan selama merawat suaminya tidak merasa direpotkan, karena itu sudah menjadi komitmensebelum berumah tangga.

2) "Sekarang Papa jangan berpikir hlm yang aneh-aneh. Yang kubutuhkan hanya kesabaran dan kekuatan Papa untuk bertahan menanti kesembuhan," "Jika Papa berpikir aneh-aneh, aku menjadi khawatir kesetiaan Papa pada janji pernikahan kita dulu." (hlm. 19)

Kutipan (2) di atas menunjukkan bahwa sang istri memiliki sifat selalu sabar dan ikhlas dikarenakan selalu mengingatkan suaminya agar tidak berpikir yang aneh-aneh, dan selalu 
member semangat untuk kesembuhan suaminya.

3) "Ya Tuhan, terima kasih atas seluruh pengalaman hidup yang Engkau anugerahkan pada keluarga kami hari ini.... "Kini kami akan makan bersama dari berkat yang Engkau limpahkan yaitu makanan dan minuman.... "Akhirnya, sudilah Engkau melindungi kami, khususnya Papa ... , untuk menikmati hari baru yang engaku sediakan. Amin!" ( hlm. 30)

Kutipan (3) di atas menunjukkan bahwa sang istri memiliki sifat selalu sabar dan ikhlas dikarenakan selalu bersyukur atas nikmat yang diberikan Tuhan kepada keluarganya.

4) "Pap, terhadap amputasi, aku sudah siap sebab melihat penderitaanmu selama ini, ... , rasanya aku tidak berdaya untuk menolak amputasi." "Demi nyawamu yang harus diselamatkan, aku yakin." "Tidak, kecuali jika hatimu ikut cacat setelah amputasi." (hlm. 73) Kutipan (4) di atas menunjukkan bahwa sang istri memiliki sifat selalu sabar dan ikhlas dikarenakan tetap menerima keadaan suaminya yang telah diamputasi.

5) "Pap, kematian adalah pilihan mutlak di ujung setiap kehidupan. Jadi, jika mati adalah... , menerima lamaran cintamu dua puluh tahun silam?" (hlm. 74)

Kutipan (5) di atas menunjukkan bahwa sang istri memiliki sifat selalu sabar dan ikhlas dikarenakan selalu mengingatkan suaminya tentang kehidupan.
6) "Ahh, tak usah Papa bicara begitu. Aku tahu Papa..., Bersyukurlah bahwa sebentar lagi kita kembali ke rumah," (hlm. 103)

Kutipan (6) di atas menunjukkan bahwa sang istri memiliki sifat selalu sabar dan ikhlas.

7) "Ahh, tak usah Papa bicara begitu. Aku tahu Papa..., Bersyukurlah bahwa sebentar lagi kita kembali ke rumah," (hlm. 103)

Kutipan (7) di atas menunjukkan bahwa sang istri memiliki sifat selalu sabar dan ikhlas dikarenakan selalu bersyukur kepada Tuhan.

\section{Aspek Berkorban Tokoh Istri dalam Novel Perempuan Itu Bermata Saga Karya Agust Dapa Loka}

1) "Apa yang bisa kulakukan?" "Seandainya sakit ini bisa dibagi, aku tidak keberatan menanggungnya bersama Papa." (hlm. 11)

Kutipan (1) di atas menunjukkan bahwa sang istri memiliki sifat rela berkorban dikarenakan selalu mengurus suaminya yang kakinya sudah diamputasi.

2) "Sekarang Papa istirahat saja. Biarku menyelesaikan kerjaan di dapur lalu pergi menjemput anak kita di sekolah." (hlm. 20)

Kutipan (2) di atas menunjukkan bahwa sang istri memiliki sifat rela berkorban dikarenakan selalu bekerja keras mengurus urusan rumah tangga dan anakanaknya.

3) "Tapi istriku melawan kantuknya sambil terus memandangiku dengan seribu perasaan yang tak dapat $k u$ pastikan. Yang pasti adalah ia telah merelakan banyak keinginannya sendiri karena harus selalu mendampingiku” (hlm. 33) 
Kutipan (3) di atas menunjukkan bahwa sang istri memiliki sifat rela berkorban dikarenakan selalu mendampingi suaminya dalam keadaan apapun.

4) "Aku mau menengok anak-anak dan mengurus rumah sebentar. Aku ragu membiarkan mereka sendirian. Sekaligus memastikan mereka menyiapkan makan siang untuk diri mereka dan Mama." (hlm. 52)

Kutipan (4) di atas menunjukkan bahwa sang istri memiliki sifat rela berkorban dikarenakan walau sesibuk apapun tetap mengurus keluarganya.

5) "Hahhh....!" Suaranya mendesah. Ia amat keletihan mengurusku dan tak banyak menikmati istirahat. Belum lagi ia harus..., dan kepentingan rumah umumnya. (hlm. 50)

Kutipan (5) di atas menunjukkan bahwa sang istri memiliki sifat rela berkorban dikarenakan selalu bersungguh-sungguh dalam mengurus rumah tangganya.

6) "Pap, hentikan kecenderungan meragukan kekuatan perempuan!" "Untuk Papa ketahui, sejak kecelakaan itu..., aku dan ketiga anak kita tak bersalah mengharapkan ketangguhan Papa." (hlm. 74)

Kutipan (6) di atas menunjukkan bahwa sang istri memiliki sifat rela berkorban dikarenakan selalu tegar menhadapi kehidupan dengan mengurus suami dan ketiga anaknya.

7) Rupanya setelah amputasi selesai, istriku mencemaskan aku daripada aku mencemaskan dirinya. Istriku memang baik, bukan tipe wanita egois. Bahkan, saat dalam ukuran sedikit." (hlm. 95)

Kutipan (7) di atas menunjukkan bahwa sang istri memiliki sifat rela berkorban dikarenakan tidak egois walau suaminya diamputasi dan tetap menjalani kehidupan dengan normal.

\section{SIMPULAN}

Berdasarkan hasil penelitian dan pembahasan yang telah dijabarkan mengenai feminisme dalam novel Perempuan Itu Bermata Saga karya Agust Dapa Loka terkandung tiga aspek. Aspek tersebut yaitu: berakhlak baik, selalu sabar dan ikhlas, dan sberkorban. Terdapat 50 kutipan kajian feminisme dalm novel Perempuan Itu Bermata Saga karya Agust Dapa Loka, berikut merupakan penjelasannya.

\section{Berakhlak baik}

Pada aspek ini, pengarang menggambar tokoh istri sebagai orang yang baik akhlaknya, tenang tabiatnya, lemah lembut, baik kata-katanya, sederhana pergaulanya, istikomah sikapnya, tidak dengki dan tidak suka balas dendam. Semua sifat yang cemerlang ini dimiliki oleh istri yang shlmehah. Ini adalah bentuk amalan yang menunjukkan kebaikan akhlaknya sungguh beruntug orang yang menikahi wanita yang berakhlak baik, menghargai orang lain dan berbicara dengan baik.

2. Selalu Sabar dan Ikhlas

Pada aspek ini, pengarang menggambar tokoh istri sebagai orang yang yang sabar dan ikhlas adalah istri yang bersabar menghadapi berbagai bencana dan tenang menghadapi goncangan. Bersabar dan memperlihatkan akidahnya yang benar terhadap qadha dan qadar. Bersabar dan ikhlas, serta mengharapkan yang ada di sisi Allah Swt.

3. Berkorban

Pada aspek ini, pengarang menggambar tokoh istri sebagai orang yang rela berkorban, dia tidak menghiraukan dirinya dan melupakan jiwanya dia mendahulukan suaminya dari pada dirinya sendiri. Dia mendahulukan 
rida, keinginan, dan apa yang disukai suaminya di atas semua kepentingan dirinya sendiri.

\section{DAFTAR PUSTAKA}

Endraswara, Suwardi. (2013). Metodologi Penelitian Sastra. Yogyakarta: CAPS.

Gunawan, E., Rahima, A., \& Supriyati, (2018). "Analisis Tema Ungkapan Tradisional Bapeno di desa Hian, Kecamatan Sitinjau Laut, Kab. Kerinci Provinsi Jambi". Aksara: Jurnal Ilmiah Pendidikan Bahasa dan Sastra Indonesia, 2(1), 130141.

Hemas, Kanjeng Ratu. (1992). Wanita Indonesia Suatu Konsepsi dan Obsesi. Yogyakarta. Liberty.

Kartono, Kartini. (1992). Psikologi Wanita. Bandung: Alumni.

Kosasih, E. (2012). Dasar-dasar Keterampilan Besastra. Bandung: YramaWidya.

Nurgiyantoro, Burhan. (1995). Teori Pengkajian fiksi. Yogyakarta: Gajah MadaUniversity Press.

Rafiek, M. (2010). Teori Sastra. Bandung: PT Refika Aditama.

Rahima, A. (2017). Literature Reception (a Conceptual Overview). Jurnal Ilmiah Dikdaya, 6(1), 1-16.

Rokhmansyah, Alfian. (2014). Studi dan Pengkajian Sastra: Perkenalan Awal Terhadap Ilmu Sastra. Yogyakarta: GrahaIlmu.

Semi, Atar. (2012). Metode Penelitian Sastra. Bandung: CV Angkasa.

Semi, M. Atar. (1990). Metode Penelitian Sastra. Bandung: Angkasa Bandung.

Siswantoro. (2010). Metode Penelitian Sastra. Yogyakarta: Pustaka Belajar.

Sumardjo, Jacob \& K. M. Saini. (2008). Apresiasi Kesusastraan. Jakarta: Gramedia.
Wahyuningtyas, Sri Santosa, Wijaya Heru. (2011). Sastra: Teori dan Implementasi. Surakarta: Yuma Pustaka.

Wiyatmi. (2009). Pengantar Kajian Sastra. Yogyakarta: Pustaka Book Publisher. 